\title{
Epidemiological study of Rift Valley fever virus in Kigoma, Tanzania
}

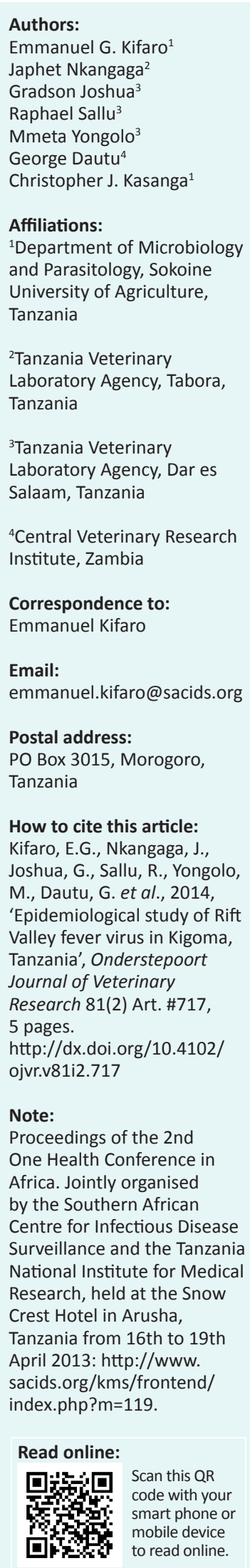

Rift Valley fever virus (RVFV) is an acute, zoonotic viral disease caused by a Phlebovirus, which belongs to the Bunyaviridae family. Among livestock, outbreaks of the disease are economically devastating. They are often characterised by large, sweeping abortion storms and have significant mortality in adult livestock. The aim of the current study was to investigate RVFV infection in the Kigoma region, which is nestled under the hills of the western arm of the Great Rift Valley on the edge of Lake Tanganyika, Tanzania. A region-wide serosurvey was conducted on non-vaccinated small ruminants (sheep and goats, $n=411$ ). Sera samples were tested for the presence of anti-RVFV antibodies and viral antigen, using commercial enzymelinked immunosorbent assay and reverse transcriptase polymerase chain reaction, respectively. The overall past infections were detected in 22 of the 411 animals, 5.4\% (Confidence Interval [CI] $95 \%=3.5 \%-8.1 \%$ ). The Kigoma rural area recorded the higher seroprevalence of $12.0 \%$ $($ CI $95 \%=7.3 \%-18.3 \% ; p<0.0001)$, followed by Kibondo at $2.3 \%$ (CI 95\% $=0.5 \%-6.5 \%$; $p>0.05)$ and the Kasulu district at $0.8 \%$ (CI $95 \%=0.0 \%-4.2 \% ; p>0.05)$. The prevalence was $12.5 \%$ and $4.7 \%$ for sheep and goats, respectively. Reverse transcriptase polymerase chain reaction results indicated that only eight samples were found to be positive $(n=63)$. This study has confirmed, for the first time, the presence of the RVFV in the Kigoma region four years after the 2007 epizootic in Tanzania. The study further suggests that the virus activity exists during the inter-epizootic period, even in regions with no history of RVFV.

\section{Introduction}

\section{Background Information}

Tanzania has experienced several Rift Valley fever virus (RVFV) epizootics or epidemics in different regions. The available records at the Ministry of Livestock, Fisheries and Development (MoLFD) indicate that RVFV occurred for the first time in Tanzania in 1930. This was followed by periodic epidemics every 10 - 20 years, for example in 1947, 1957, 1977, 1997 and 2007 (Sindato et al. 2011). In 2007, the disease was initially concentrated in the northern parts of the country that border Kenya (Ngorogoro and Monduli in the Arusha region). Between February and June 2007, other regions of Tanzania, including Manyara, Tanga, Dodoma, Morogoro, Dar es Salaam, Coast, Iringa, Mwanza and Singida, reported cases of RVFV in humans and animals (Nderitu et al. 2011).

RVFV is a viral disease of animals and humans that occurs throughout Sub-Saharan Africa, Egypt and the Arabian Peninsula. Outbreaks of the disease are episodic and closely linked to climate variability. It is especially widespread during elevated rainfall, as this facilitates RVFV transmission by vector mosquitoes (Linthicum et al. 1987). These mosquitoes are thought to initiate outbreaks among livestock; breeds of sheep and cattle are particularly susceptible. Human infections follow as the result of either direct mosquito transmission or from percutaneous or aerosol routes during the handling of aborted foetal materials or the slaughtering of infected livestock. The acute onset of large numbers of affected individuals and livestock during outbreaks can greatly strain public health and veterinary infrastructures (Bird et al. 2008).

The severity of RVFV, its ability to cause major epidemics among livestock and humans, and the lack of efficient prophylactic and therapeutic measures make infection with this pathogen a serious public health concern, not only in endemic, developing countries, but also in many nonendemic industrial countries (Bouloy \& Weber 2010).

The present study reports the presence of RVFV infections during the inter-epizootic period (IEP) and in a region known to be free from RVFV. The Kigoma region has never experienced a RVFV epidemic or epizootic, unlike other regions that are found on the eastern arm of the Great Rift Valley. It is expected that the findings from this study will help in providing the scientific-based evidence on the presence of RVFV infections in such regions and that it will improve the policies on control programmes of the disease in Tanzania and worldwide. 


\section{Materials and methods}

\section{Study area}

The Kigoma region is located on the shores of Lake Tanganyika in the north-west corner of Tanzania. It shares boundaries with Burundi and the Kagera region to the north, Shinyanga and Tabora regions to the east, Congo to the west and Rukwa region to the south. It has a wonderful natural beauty, nestled under the hills of the western arm of the Great Rift Valley on the edge of the Lake. The vegetation in the Kigoma region is comprised of closed and open woodland, which covers about $70 \%$ of the land area and includes bushy grassland and swamps of various coverage (Regional Commissioner's Office: Kigoma 2008). In the Kibondo district there is Moyowosi Game Reserve, which covers an area of $6000 \mathrm{~km}^{2}$ and is situated on the edge of the great central plateau between the east and western Rift Valley arms; it has an altitude ranging from $800 \mathrm{~m}-1600 \mathrm{~m}$. The reserve is recognised as supporting large populations of buffalo, topi, lion, giraffe, zebra, hartebeest, roan antelope, greater kudu, waterbuck sitatunga, hippo and crocodile (Ministry of Natural Resources and Tourism 2012).

\section{Study design}

A simple cross sectional study was conducted, using archived serum samples that were collected from September 2011 to October 2011, amongst livestock (sheep and goats) in three out of four districts that formally make up the Kigoma region. Samples were collected along the Tanzania-Burundi border between Nyanzige village in the north and Nsunuka in the south.

\section{Sample collection and preparation \\ Blood sample collection}

A total of 32 sheep and 379 goats had blood samples collected by venipuncture. Blood samples from three districts in the Kigoma region were collected from small ruminants during the IEP after the rainy season and early winter. Blood was collected from 45 villages in the region.

\section{Preparation of serum}

Serum used in this study was collected between May 2011 and June 2011. The blood samples were left to coagulate and were later separated to obtain serum, which was transported to the laboratory under cold conditions and stored at $-35{ }^{\circ} \mathrm{C}$ until it was used for detection of anti-RVFV antibodies and viral genome (M-segment) by reverse transcriptase-polymerase chain reaction (RT-PCR).

\section{Laboratory analysis of samples} An inhibition enzyme-linked immunosorbent assay for
detection of Rift Valley fever virus antibodies

The enzyme-linked immunosorbent assay (ELISA) kit (Biological Diagnostic Supplies Limited [BDSL] Scotland, UK) was used according to the manufacturer's protocols (Paweska et al. 2005).

\section{Extraction of viral nucleic acid from serum}

Viral RNAs were extracted from the serum samples using a QIAamp Viral RNA Kit (QIAGEN, Valencia, CA, USA) according to the manufacturer's instructions.

\section{Reverse transcriptase-polymerase chain reaction}

Single-tube RT-PCR amplification was carried out using a One-Step Access RT-PCR system (AgPath-ID ${ }^{\mathrm{TM}}$ One-Step RTPCR Kit, Applied Biosystems, USA). This was comprised of:

- $25 \mu \mathrm{L}$ reaction mixture contained in final concentration with $12.5 \mu \mathrm{L}$ of 2 x RT-PCR buffer

- $2.0 \mu \mathrm{L}$ of 25 picomole of both forward and reverse primers

- $1.0 \mu \mathrm{L}$ of $25 x$ Enzyme mix

- $1.7 \mu \mathrm{L}$ of Detection enhancer

- $5.0 \mu \mathrm{L}$ of target RNA.

The total volume was brought to $25.0 \mu \mathrm{L}$ using RNase free water. The cycling program consisted of a reverse transcription step at $37^{\circ} \mathrm{C}$ for $30 \mathrm{~min}$, followed by 45 cycles of denaturation at $94{ }^{\circ} \mathrm{C}$ for $30 \mathrm{~s}$, annealing temperatures at $65^{\circ} \mathrm{C}$ for $30 \mathrm{~s}$ each and extension at $72{ }^{\circ} \mathrm{C}$ for $30 \mathrm{~s}$. The reaction mixture in each polymerase chain reaction (PCR) tube was then subjected to a final extension step at $72{ }^{\circ} \mathrm{C}$ for $7 \mathrm{~min}$. All PCR amplifications were carried out at a $25 \mu \mathrm{L}$ volume per tube. Thermal profiles were performed on a GeneAmp PCR system 9700 (Applied Biosystems, USA). One set of primer RVF 1 FWD Forward: 5'-GAC TAC CAG TCA GCT CATT ACC-3' and RVF 2 REV Reverse: 5'-TGT GAA CAA TAG GCA TTG G-3' targeting a 551 base pair fragment of the M-segment of RVFV was used during the PCR testing. Following amplification, $10 \mu \mathrm{L}$ from each PCR tube containing amplified product was loaded onto gels of $2.0 \%$ (SeaKem agarose Bioproduct, Rockland, Maryland, USA) and electrophoresed. The gels were stained with ethidium bromide and the PCR products were visualised under UV light.

\section{Data analysis}

All the data were compiled in Microsoft Office-Excel 2007 (Microsoft, USA). The serological data were analysed using Epi info ${ }^{\mathrm{TM}}$ version 3.5.1 software (CDC, Atlanta, USA). The Chi-square test was used to analyse data by comparing different groups of collected data for statistical significance. The individual serological status was the binomial response and the previously mentioned variables (age, sex and species) were the explicative factors.

\section{Results}

\section{Seroprevalence of Rift Valley fever virus}

Overall RVF seroprevalence was 5.4\% (Confidence Interval, CI 95\%, 3.5\% - 8.1\%) in the three sampled districts (Table 1). The Kigoma rural district recorded higher seroprevalence $12.0 \%$ (CI 95\%, 7.3\% - 18.4\%) compared to the seroprevalences of $2.3 \%$ and $0.8 \%$ in the Kibondo and Kasulu districts, respectively. The difference was also statistically significant $(p<0.0001)$. 
During univariate analysis (Table 2) there was no statistical difference in the seroprevalence recorded in goats $(4.7 \%)$ compared to that in sheep (12.5\%). Similarly, there was no statistical difference in the RVFV seroprevalence in female animals (4.5\%) compared to male animals (8.2\%) sampled in this study. Age-wise, $5.5 \%$ of the adults and $4.8 \%$ of the kids or lambs were seropositive; however, there was no statistical difference observed.

\section{Single tube reverse transcriptase-polymerase chain reaction}

Rift Valley fever virus RNA was detected in 63 serum samples by RT-PCR, which showed high percentage inhibition (PI) on ELISA assay. Out of the 63 serum samples with high PI, RVFV genome was detected in eight samples (12.7\%) from all three districts (Table 3).

\section{Discussion}

The result of this serosurvey and genome detection targeting medium-size (M) segments in domesticated small ruminants suggests that RVFV has circulated in all the three sampled districts of the Kigoma region (Figure 1). This study was conducted four years after the 2006/2007 RVFV outbreak, which was the largest RVFV outbreak documented in Tanzania

TABLE 1: Prevalence of Rift Valley fever virus infections in Kigoma, Tanzania, May 2011 to June 2011.

\begin{tabular}{lllll}
\hline District & $\begin{array}{l}\text { Sample } \\
\text { size }\end{array}$ & $\begin{array}{l}\text { Positive } \\
\text { samples }\end{array}$ & $\begin{array}{l}\text { Prevalence } \\
(\mathbf{\%})\end{array}$ & $p$-value \\
\hline Kigoma rural (KG) & 150 & 18 & 12.0 & $p<0.0001$ \\
Kibondo (KB) & 132 & 3 & 2.3 & - \\
Kasulu (KS) & 129 & 1 & 0.8 & - \\
\hline Total & $\mathbf{4 1 1}$ & $\mathbf{2 2}$ & $\mathbf{5 . 4}$ & - \\
\hline
\end{tabular}

TABLE 2: Univariate Analysis between Seroprevalence of Rift Valley fever virus infections and age, sex and species in Kigoma, Tanzania, May 2011 to June, 2011. Demographic Category Sample Positive Negative Prevalence $p$-value $\begin{array}{lllll}\text { data } & \text { size } & \text { samples } & \text { samples } & (\%)\end{array}$

\begin{tabular}{lllllll}
\hline Age & Adults & 348 & 19 & 329 & 5.5 & 1.0000
\end{tabular}

$\begin{array}{llllllll} & \text { Sub-adults } & 63 & 3 & 60 & 4.8 & \\ & \text { Total } & \mathbf{4 1 1} & \mathbf{2 2} & \mathbf{3 8 9} & - & \\ \text { Sex } & \text { Males } & 97 & 8 & 89 & 8.2 & 0.1473\end{array}$

$\begin{array}{lllll}\text { Females } & 314 & 14 & 300 & 4.5\end{array}$

\begin{tabular}{|c|c|c|c|c|c|c|}
\hline & IOtar & 411 & 22 & 505 & 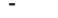 & \\
\hline \multirow[t]{3}{*}{ Species } & Sheep & 32 & 4 & 28 & 12.5 & \multirow[t]{3}{*}{0.0815} \\
\hline & Goats & 379 & 18 & 361 & 4.7 & \\
\hline & Total & 411 & 22 & 389 & - & \\
\hline
\end{tabular}

Note: Sub-adults, animals below one year of age.
(Mohamed et al. 2010). It affected 10 of the 21 regions in the country and 25 of the 126 districts. It resulted in over 300 suspected cases of RVFV and had a human case-fatality rate of $47 \%$. This was higher than the previously reported outbreaks of 2000/2001 in Saudi Arabia (14\%) and 2006/2007 in Kenya (26.4\%) (Balkhy \& Memish 2003; Mohamed et al. 2010).

The presence of significant levels of anti-RVFV IgG antibody against RVFV in the districts studied indicates that the virus could be circulating during this IEP. The vaccine against RVFV had not been used in any of the districts during a period of at least four years prior to this study. In most locations, RVFV antibodies were detected in animals aged less than one year (sub-adults) and over one year (adults). This showed

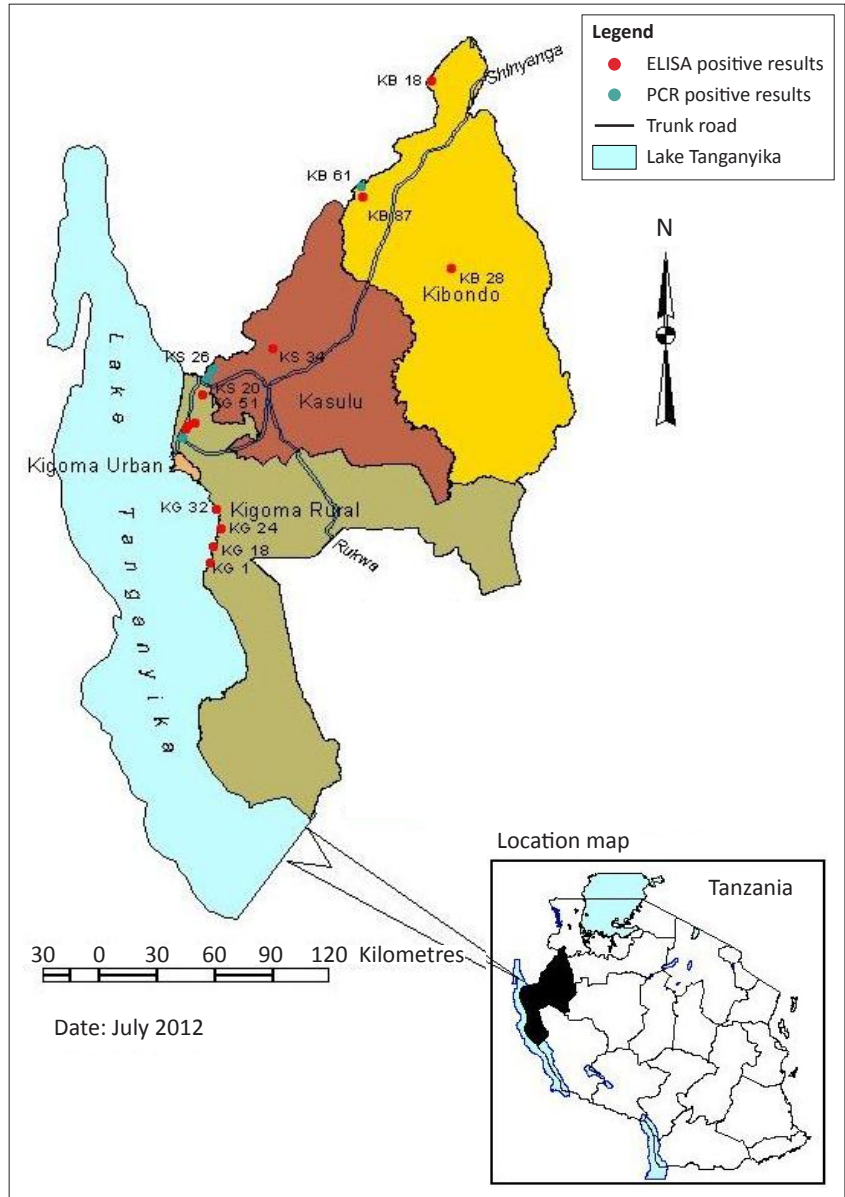

Source: Kifaro et al. (2013)

FIGURE 1: Map of Kigoma region showing the three districts where some of the Rift Valley fever virus-positive sheep and goats were identified.

TABLE 3: Serum samples that showed positive results on polymerase chain reaction.

\begin{tabular}{|c|c|c|c|c|c|c|c|}
\hline District & Sample ID & Species & Sex & Age & ELISA results & PI-OD & PCR results \\
\hline Kigoma rural (KG) & KG 126 & Goats & Female & Adult & - & 4.08 & + \\
\hline \multirow[t]{4}{*}{ Kibondo (KB) } & KB 28 & Goats & Female & Adult & - & 9.97 & + \\
\hline & KB 61 & Goats & Female & Adult & - & 2.47 & + \\
\hline & KB 80 & Goats & Female & Adult & - & 2.73 & + \\
\hline & KB 87 & Goats & Female & Sub-Adult & - & 20.91 & + \\
\hline \multirow[t]{3}{*}{ Kasulu (KS) } & KS 20 & Sheep & Female & Adult & - & 4.27 & + \\
\hline & KS 26 & Goats & Female & Adult & - & 4.05 & + \\
\hline & KS 34 & Goats & Female & Adult & - & 5.22 & + \\
\hline
\end{tabular}

KG, Kigoma rural; KB, Kibondo; KS, Kasulu; ID, Identification number; PI-OD, Percent Inhibition-Optic density; PCR, Polymerase chain reaction; ELISA, enzyme-linked immunosorbent assay. Note: Sub-adult, animals below one year of age. 
endemic presence of the virus in different parts of the region. Olaleye et al. (1996), in Nigeria, observed similar results.

The Kigoma rural district recorded higher seroprevalence (12.0\%) compared to $2.3 \%$ and $0.8 \%$ in the Kibondo and Kasulu districts, respectively $(p<0.0001)$. Similar results were reported in Senegal in 1994, with an RVFV IgG prevalence of $40.0 \%(n=40)$ and $\operatorname{IgM}$ of $12.5 \%, 10$ years after RVFV (Thonnon et al. 1999). Species wise, sheep had a higher seroprevalence of $12.5 \%$ compared to goats, with $4.7 \%$. This has been observed in several other studies (Olaleye et al. 1996; Rostal et al. 2010; Jeanmaire et al. 2011) from Nigeria, Kenya and Madagascar, respectively. This shows how sheep act as good primary amplifying hosts of RVFV. Apart from sheep, RVF can affect many other species of animals, including cattle, buffalo, camels and monkeys, as well as grey squirrels and other rodents. However, the primary amplifying hosts are sheep and cattle (International Office of Epizootics 2007).

The Kigoma rural district is joined together with Ujiji or Kigoma town, which is the regional headquarters as well as the largest port of Lake Tanganyika. It is linked to other regions by the railway line and trunk road. This makes it a business city with a lot of activities, including the livestock trade (National Sample Census of Agriculture 2008). There is an inadequate number of livestock for slaughter in the region, as it is said that most livestock are not very tender. Therefore, most animals are imported for that reason and are brought in and transported by railways and roads from the neighbouring regions to different destinations (Regional Commissioner's Office, Kigoma 2008). Animal transportation or movement from other regions to Kigoma for trade and/or pastures has probably played a major role in the spread of infection within the region. In Madagascar, Chevalier et al. (2011) observed that anti-RVFV IgG seroprevalence of bovines belonging to breeders that purchased livestock to renew their herd was $28.1 \%(p=0.04)$. Introduction of RVFV to new areas has been linked to livestock movement; this was previously implicated as a possible route for the introduction of RVFV into Egypt during the 1977 outbreak (Gad et al. 1986).

In Kibondo and Kasulu districts, the seroprevalence differences were not significant $(p>0.05)$. Animal movement, coupled with the presence of the Moyowosi Game Reserve, which covers an area of $6000 \mathrm{~km}^{2}$ and supports large populations of wildlife species, could be the supporting factors of RVFV transmission in the Kibondo district (Ministry of Natural Resources and Tourism 2012). The presence of wildlife species in the game reserve that have been proven to have RVFV antibodies during IEP might also be a risk factor. Evans et al. (2008) reported the highest prevalence of RVFV antibodies in ruminant wildlife in Kenya. Buffalo, which comprised the largest number of specimens $(n=342)$, had both a high prevalence of RVFV antibodies (16.95\%) and also significantly higher titres of viral neutralising antibodies compared to other animal species. Furthermore, wildlife-mosquito cycles may result into low-level livestock infections. Data in countries where RVFV outbreaks occur suggest that between $2.50 \%$ and $23.00 \%$ of livestock may have been infected by RVFV during an IEP (Swanepoel 1981; Dohm et al. 2000).
In this study, there was no significant difference in the seroprevalence recorded in goats $(4.7 \%)$ compared to that in sheep (12.5\%). Similarly, there was no significant difference in the RVFV seroprevalence in females $(4.5 \%)$ compared to males $(8.2 \%)$. Age-wise, $5.5 \%$ of the adults compared to $4.8 \%$ of the kids or lambs were seropositive; the low number of sampled animals, especially sheep, could not justify significance of the univariate analyses done and account for this. As compared to other studies, the prevalence of recent infections per district ranged from $5.9 \%(0.0-2.4)$ to $10.6 \%$ (5.6-15.5) in sheep and from $0.8 \%(0.0-1.9)$ to $3.3 \%(0.0-6.9)$ in goats. In a study done in Madagascar (Jeanmaire et al. 2011), prevalence of past infections was significantly higher in male cattle than in female cattle $(p<0.001)$ and in small ruminants $(p<0.001)$.

Polymerase chain reaction provides a sensitive and specific detection of RVFV in cell culture and directly in serum samples from infected humans and animals (Sall et al. 1999). The current study targeted the M-segment in the detection of the viral genome using gene-specific primers. The study did not find any correlation between positive ELISA and RT-PCR results, as all ELISA-positive samples tested negative on RTPCR. This is due to the fact that after the incubation period of four to six days, a virus is usually demonstrated in the blood during the febrile period (three - four days), whereas neutralising antibodies also start appearing around the fourth day of onset of symptoms (Findlay \& Daubrey 1931). In the case of RVFV, PCR is more sensitive in the detection of the early to acute viraemic phase of infection, which occurs between four to eight days after infection. This explains the presence of active viral activities and recent RVFV infection transmissions in the region.

\section{Acknowledgements}

The authors would like to thank Dr Japhet Nkangaga, of the Tanzania Veterinary Laboratory Agency, Tabora, Tanzania for his kind donation of serum samples for this study. We also wish to extend our gratitude to Welcome Trust through Southern African Centre for Infectious Disease Surveillance (SACIDS) for their financial support for this project. This work was supported by the Wellcome Trust Grant WT087546MA to the Southern African Centre for Infectious Diseases \& Surveillance (SACIDS).

\section{Competing interests}

The authors declare that they have no financial or personal relationship(s) that may have inappropriately influenced them in writing this article.

\section{Authors' contributions}

E.K. (Sokoine University of Agriculture) was the project leader and was responsible for most of the laboratory work, project design and writing of the manuscript. G.J. (Tanzania Veterinary Laboratory Agency, Dar es Salaam) and R.S. (Tanzania Veterinary Laboratory Agency, Dar es Salaam) 
greatly assisted in analysis of samples of both ELISA and RT-PCR, respectively. M.Y. (Tanzania Veterinary Laboratory Agency, Dar es Salaam) made conceptual contributions on results interpretation and supervision of laboratory work. J.N. (Tanzania Veterinary Laboratory Agency, Tabora) performed sample collection, data cleaning and assisted in analysis of data. G.D. (Central Veterinary Research Institute, Zambia) and C.J.K. (Sokoine University of Agriculture) reviewed the manuscript and were overall supervisors of the work.

\section{References}

Balkhy, H.H. \& Memish, Z.A., 2003, 'Rift Valley fever: An uninvited zoonosis in the Arabian Peninsula', International Journal of Antimicrobial Agents 21, 153-157. $\mathrm{http}: / / \mathrm{dx}$.doi.org/10.1016/S0924-8579(02)00295-9

Bird, B.H., Githinji, J.W.K., Macharia, J.M., Kasiiti, J.L., Muriithi, R.M., Gacheru, S.G. et al., 2008, 'Multiple virus lineages sharing recent common ancestry were associated with a large Rift Valley fever outbreak among livestock in Kenya during 2006-2007', Journal of Virology 82, 11152-11166. http://dx.doi.org/10.1128/JVI.01519-08

Bouloy, M., Weber, F., 2010, 'Molecular Biology of Rift Valley Fever Virus', The Open Virology Journal 4, 8-14.

Chevalier, V., Rakotondrafara, T., Jourdan, M., Heraud, J.M., Andriamanivo, H.R., Durand B. et al., 2011, 'An Unexpected Recurrent Transmission of Rift Valley Fever Virus in Cattle in a Temperate and Mountainous Area of Madagasca', PLoS Negleted Tropical Diseases 5(12), viewed 12 July 2012, from http://www.plosntds.org/ article/info\%3Adoi\%2F10.1371\%2Fjournal.pntd.0001423

Dohm, D.J., Rowton, E.D., Lawyer, P.G., Monica O'Guinn, M. \& Turell, M.J., 2000 'Laboratory Transmission of Rift Valley Fever Virus by Phlebotomus duboscqi, Phlebotomus papatasi, Phlebotomus sergenti, and Sergentomyia schwetzi (Diptera: Psychodidae)', Journal of Medical Entomology 37, 35-438. http://dx.doi.org/10.1603/ 0022-2585(2000)037[0435:LTORVF]2.0.CO;

Evans, A., Gakuya, F., Paweska, J.T., Rostal, M., Akoolo, L., Van Vuren, P.J. et al., 2008 , 'Prevalence of Antibodies against Rift Valley Fever Virus in Kenyan Wildlife', Epidemiology and Infection 36, 1261-1269.

Findlay, G.M., Daubney, R., 1931, 'The virus of rift valley fever or enzootic hepatitis', Lancet 221, 1350-1351. http://dx.doi.org/10.1016/S0140-6736(00)99624-7

Gad, A.M., Feinsod, F.M., Allam, I.H., Eisa, M., Hassan, A.N., Soliman, B.A. et al., 1986, 'A possible route for the introduction of Rift Valley fever virus into Egypt during 1977', Journal of Tropical Medicine and Hygiene 89, 233-236.
Jeanmaire, E.M., Rabenarivahiny, R., Biarmann, M., Rabibisoa, L., Ravaomanana, F. Randriamparany, T. et al., 2011, 'Prevalence of Rift Valley Fever Infection in Ruminants in Madagascar after the 2008 Outbreak', Vector-Borne Zoonotic Diseases 11(4), 395-402. http://dx.doi.org/10.1089/vbz.2009.0249

Linthicum, K.J., Bailey, C.L., Glyn, D.F. \& Tucker, C.J., 1987, 'Detection of Rift Valley fever viral activity in Kenya by satellite remote sensing imagery', Science 235 1656-1659. http://dx.doi.org/10.1126/science.3823909

Ministry of Natural Resources and Tourism Tanzania (MNRT), viewed 21 July 2012, from http://www.mnrt.go.tz

Mohamed, M., Mosha, F., Mghamba, J., Zaki, S.R., Shieh, W.J., Paweska, J. et al., 2010, 'Epidemiologic and clinical aspects of a rift valley fever outbreak in humans in Tanzania, 2007', American Journal of Tropical Medicine and Hygiene 83(2), 22-27. http://dx.doi.org/10.4269/ajtmh.2010.09-0318

Nderitu, L., Lee, J.S., Omolo, J., Omulo, S., O'Guinn, M.L., Hightower, A. et al., 2011, 'Sequential Rift Valley fever outbreaks in eastern Africa caused by multiple lineages of the virus', Journal of Infectious Diseases 1203, 655-665. http://dx.doi.org/ 10.1093/infdis/jiq004

Office International des Epizooties (OIE) 2007, Rift Valley Fever. Infectious Enzootic Hepatitis of Sheep and Cattle Fact sheet, OIE, Paris.

Olaleye, O.D., Tomori, O., Schmitz, H., 1996, 'Rift Valley fever in Nigeria: Infections in domestic animals', Review of science and technology, Office International des Epizooties 15(3), 937-946.

Paweska, J.T., Mortimer, E., Leman, P.A. \& Swanepoel, R., 2005, 'An inhibition enzyme linked immunosorbent assay for the detection of antibody to Rift Valley fever in humans, domestic and wild ruminants', Journal of Virology 127, 10-18.

Regional Commissioner's Office: Kigoma Region, 2008, Socio-Economic Profile, pp. 148, National Bureau of Statistics (Nbs) and Kigoma Regional Commissioner's Office, Regional Report.

Rostal, M.K., Evans, A.L., Sang, R., Gikundi, S., Wakhule, L., Munyua, P. et al., 2010 'Identification of potential vectors of and detection of antibodies against Rift Valley fever virus in livestock during interepizootic periods', American Journal of Veterinary Research 71(5), 522-526. http://dx.doi.org/10.2460/ajvr.71.5.522

Sall, A.A., Zanotto, P.M., Sene, O.K., Zeller, H.G., Digoutte, J.P., Thiongane, Y. et al., 1999 'Genetic reassortment of Rift Valley Fever virus in nature', Journal of Viroogy 73, 8196-8200

Sindato, C., Karimuribo, E. \& Mboera, L.E.G., 2011, ‘The epidemiology and socio-economic impact of rift valley fever epidemics in Tanzania', Tanzania Journal of Health Research 13(5), suppl. 1, 1-16.

Swanepoel, R., 1981, 'Observations on Rift Valley Fever in Zimbabwe', Contributions to Epidemiology and Biostatistics 3, 383-391.

Thonnon, J., Picquet, M., Thiongane, Y., Lo, M., Sylla, R. \& Vercruysse, J., 1999, 'Rift valley fever surveillance in the lower Senegal River basin: Update 10 years after the epidemic', Tropical Medicine and International Health 4(8), 580-585. 